\title{
Pulmonary vascular remodeling and right heart failure in pulmonary hypertension: future role of positron emission tomography in decoding the enigma
}

\author{
Hendrik J Harms², Mariëlle C van de Veerdonk', Adriaan A Lammertsma², Anton Vonk Noordegraaf ${ }^{1}$ \\ and Harm Jan Bogaard ${ }^{*}$
}

\begin{abstract}
Whereas the insights into the cellular and molecular mechanisms of pulmonary arterial hypertension (PAH) and associated right heart failure have increased in recent years, there is a lack of clinical tools to assess the pathobiological mechanisms in patients. Positron emission tomography (PET) provides an array of new possibilities to image and quantify relevant disease processes, including proliferation, angiogenesis, matrix remodeling, shifts in metabolism and neurohormonal signaling. Here we describe the first studies which were conducted to image pulmonary vascular remodeling and right heart failure in vivo and discuss additional targets for imaging which hold great promise for future use in PAH patients.
\end{abstract}

Keywords: Pulmonary hypertension; Right heart; Positron emission tomography; Glycolysis; Proliferation; Extracellular matrix; Oxygen uptake

\section{Introduction}

Pulmonary arterial hypertension $(\mathrm{PAH})$ is a deadly disease characterized by vasoconstriction and abnormal remodeling of pulmonary vessels, leading to a progressive increase in pulmonary artery pressure. Key to patient outcome is the response of the right ventricle (RV) to the functional, cellular and molecular alterations in the pulmonary circulation [1-3]. Although rare (PAH has a prevalence of 26 cases per million adult population) [4], the disease occurs most frequently at a young age and is associated with a severely reduced life expectancy [5]. More than ten different drugs are currently registered for the treatment of $\mathrm{PAH}$; all are rather specific pulmonary vasodilators with modest effects on abnormal vascular remodeling. While partial unloading of the heart by these drugs does improve symptoms, there is no cure or major survival benefit after medical treatment [5]. In animal models there is evidence that PAH specific treatments may directly affect RV function, independently from their effects on the pulmonary circulation $[6,7]$.

\footnotetext{
* Correspondence: hj.bogaard@vumc.nl

${ }^{1}$ Department of Pulmonary Medicine, VU University Medical Center, PO Box 7057, Amsterdam, MB 1007, The Netherlands

Full list of author information is available at the end of the article
}

The use of cardiac-specific drugs to improve RV function in PAH has only recently been considered and primarily involves interventions in neuro-hormonal signaling and metabolic remodeling [8-10].

The introduction of new compounds for the treatment of PAH and associated RV failure has been seriously hampered by the lack of methods to directly assess the primary disease processes in patients. Neither crude estimates of a subject's exercise capacity, nor invasively determined hemodynamic profiles provide direct information on the biological responses of the lung vasculature and heart to medical treatments. The distance walked in 6 minutes is used as primary endpoint in most drug trials in PAH, but the validity of this outcome parameter as a surrogate for clinical outcome has been seriously questioned [11]. The fear for complications has prohibited the use of lung or cardiac biopsies to determine organ specific cellular and molecular changes at the time of diagnosis or during follow-up. There is a great unmet need for imaging methods that aid diagnostic classification and which can reflect and predict responses to treatment. In this review, we will discuss the opportunities and limitations of Positron Emission Tomography (PET) to assess lung vascular 
remodeling and RV adaptation in PAH patients. PET is a non-invasive imaging modality that allows for quantitative in vivo measurements of molecular processes. PET imaging has only recently been applied in PAH patients and has far from reached its full potential.

\section{In vivo assessment of lung vascular remodeling}

The increased pulmonary vascular resistance in PAH is thought to come about through a combination of vasoconstriction, vascular occlusions and vascular loss. Among the multiple factors implicated in the etiology of these lung vascular abnormalities are genetic mutations, infection and inflammation, increased shear stress and a derailed regulation of processes of cellular growth and apoptosis [12]. Several of the cellular and molecular changes which take place in the PAH vasculature, are potential imaging targets. So far, PET imaging in PAH has been restricted to the quantification of increased glucose uptake and phosphorylation by using 18 -fluorodeoxyglucose $\left({ }^{18} \mathrm{~F}\right.$-FDG) tracers. Technical issues specifically pertaining to PET scanning of the lungs are 1) the necessity of corrections for lung density and in-field respiratory movements, and 2) the appropriate choice of input functions. Input functions reflect the supply of radiotracer from the blood to the tissues and are vital for the accurate quantification of PET data. In most applications of PET scanning, tracer activity is measured in the systemic arterial blood to reflect tracer supply to the organs or tissue of interest. If tracers are metabolized during the scanning session, the input function is corrected for the presence of radioactive metabolites and plasma activity concentrations. Identifying an input function for PET imaging of the lungs is complicated due to the existence of dual perfusion systems: the pulmonary and the systemic circulation. This issue is further challenged in $\mathrm{PAH}$ by the fact that the relative contributions of the two circulations to total lung perfusion may vary between patients.

\section{Aerobic glycolysis: the Warburg effect}

A distinct feature of vascular remodeling in animal models and in human PAH is abnormal cellular metabolism, where several cell types in the lung vascular wall, despite ample supply of oxygen, show greater reliance on cytoplasmic glycolysis as opposed to mitochondrial oxidation of glucose or fatty acids [13,14]. Aerobic glycolysis, or the Warburg effect, is a feature found in malignancies and in nonmalignant tissues harboring fast-proliferating cells, including inflammatory cells. ${ }^{18}$ F-FDG PET scanning has been successfully used to quantify increased uptake and phosphorylation of glucose in the PAH lung [13-15], but negative data have also been reported [16]. While discrepancies between studies may be explained by differences in patient preparation, scanning protocols and data analysis (e.g. absolute quantification with dynamic PET scanning is likely superior to determining standardized uptake values in a static scan), it is becoming clear that ${ }^{18}$ F-FDG uptake in the PAH lung is highly variable, does not correlate to disease severity or survival, and rapidly normalizes upon PAH treatment $[14,16]$. Therefore, clinical applicability of ${ }^{18}$ F-FDG PET scanning in PAH seems limited. For a summary of the advantages and disadvantages of ${ }^{18}$ F-FDG PET scanning in PAH: see Table 1.

In addition to ${ }^{18} \mathrm{~F}$-FDG, ${ }^{11} \mathrm{C}$-acetate [17] may have a role as a tracer for PET-imaging based quantification of the Warburg effect in PAH. After its uptake in tissue, ${ }^{11} \mathrm{C}$-acetate is oxidized in the citric acid cycle and its metabolite, ${ }^{11} \mathrm{C}-\mathrm{CO}_{2}$, is excreted from the tissue [18]. The rate of excretion of tracer activity is a quantitative measure of this oxidation step and, consequently, of oxygen use. When metabolism shifts away from fatty acid oxidation and moves towards glycolysis, as is the case in the PAH lung, ${ }^{11} \mathrm{C}$-acetate excretion rates are expected to be reduced relative to healthy lungs (Figure 1). Measured excretion rates are insensitive to differences in lung density, as lung density only affects the absolute scaling of tracer activity but not tracer clearance rates. In addition, a simplified measure of the excretion rate: K-mono, can be derived by fitting an exponential function through the downslope of the tissue curve [19]. The use of K-mono requires no input function, overcoming some of the technical issues mentioned before. For these reasons, ${ }^{11} \mathrm{C}$-acetate may potentially be used as an alternative to ${ }^{18}$ F-FDG for research and treatment response purposes. However, data confirming this hypothesis are currently lacking and more studies are warranted.

\section{Proliferation}

Several cell types in the PAH lung exhibit increased proliferation rates, including endothelial cells, smooth muscle cells and adventitial cells (fibroblasts and others) [12]. Proliferation rates are readily picked up by continuous incorporation of thymidine in rapidly dividing cells, which provides another opportunity for imaging of the $\mathrm{PAH}$ lung. When ${ }^{18}$ F-labeled fluorothymidine (FLT) is injected into the blood, it builds up in rapidly dividing cells [20] and can be imaged by a PET scanner. This relatively straightforward imaging method has yet to be tested in PAH. Preclinical data shows that the increased growth potential of cells in the PAH lung is also reflected by expression of growth factor receptors, including platelet derived growth factor receptor (PDGF-R) [21], fibroblast growth factor receptor (FGF-R) [22] and epidermal growth factor receptor (EGF-R) [23]. Signaling through these receptors is mediated by receptor tyrosine kinases, and receptor tyrosine kinase inhibitors are not only being developed as drugs, but also as PET tracers [24]. These tracers can perhaps be used to quantify lung vascular remodeling and predict treatment responses in $\mathrm{PAH}$, but this hypothesis remains untested. 
Table 1 Clinical advantages and disadvantages of ${ }^{18} \mathrm{~F}$-FDG PET scanning in PAH

\begin{tabular}{|c|c|}
\hline \multirow[t]{3}{*}{ Advantages } & - Commonly available in many hospitals \\
\hline & - Easy to manufacture and easy to transport \\
\hline & $\begin{array}{l}\text { - Mechanisms which predict an altered tracer activity in } \\
\text { PAH have been relatively well studied }\end{array}$ \\
\hline \multirow[t]{6}{*}{ Disadvantages } & $\begin{array}{l}\text { - No consensus exists on appropriate patient } \\
\text { preparation prior to imaging (e.g. Overnight fasting } \\
\text { and glucose loading), leading to inconsistencies in } \\
\text { results between centers }\end{array}$ \\
\hline & $\begin{array}{l}\text { - Lung and right ventricular }{ }^{18} \mathrm{~F}-\mathrm{FDG} \text { uptake does not } \\
\text { correlate with disease severity or survival }\end{array}$ \\
\hline & $\begin{array}{l}\text { - Lung and right ventricular }{ }^{18} \mathrm{~F}-\mathrm{FDG} \text { uptake rapidly } \\
\text { normalize upon PAH treatment, questioning the } \\
\text { utility of }{ }^{18} \mathrm{~F} \text {-FDG PET in the follow-up of patients }\end{array}$ \\
\hline & - Corrections for lung density have not been performed \\
\hline & $\begin{array}{l}\text { - Increased FDG uptake in the heart could either } \\
\text { reflect an increase in }\end{array}$ \\
\hline & $\begin{array}{l}\text { - After load or a direct, after load-independent, change } \\
\text { in energy metabolism. It is not possible to determine } \\
\text { the relative contributions of both processes }\end{array}$ \\
\hline
\end{tabular}

\section{Extracellular matrix remodeling and angiogenesis}

Vascular remodeling in $\mathrm{PAH}$ has been compared to a process of uncontrolled angiogenesis [12]. Several steps in the angiogenic process, such as endothelial cell migration, proliferation, survival and differentiation are regulated by integrins. The $\alpha_{\mathrm{v}} \beta_{3}$ and $\alpha_{5} \beta_{1}$ integrins are cell adhesion receptors which are over-expressed in the PAH lung in comparison to the normal lung [22,25] and bind to a variety of extracellular matrix proteins containing an arginine-glycine-aspartic acid (RGD) sequence, such as vitronectin and fibronectin. As such, radiolabeled RGD analogues can perhaps be used for imaging of angiogenesis in PAH. Dijkgraaf et al. showed that dimeric RGD peptides accumulate in $\alpha_{\mathrm{v}} \beta_{3}$ integrin expressing tumors more efficiently than the original monomeric analogues [26] and they developed a dimeric ${ }^{18} \mathrm{~F}$ galacto-RGD analogue: (cRGDfK)2-DOTA for PET imaging [27]. A tracer currently under development is a matrix metalloproteinase (MMP)-9 tracer, which would allow assessment of extracellular matrix remodeling. Other tracers which could be of specific interest to study vascular remodeling in $\mathrm{PAH}$ are e.g. markers of transforming growth factor $\beta$ and bone morphogenic protein signaling [28].

\section{In vivo imaging of right heart adaptation and failure}

The response of the RV to the increased load in PAH is the end-result of multiple interactions between autocrine, paracrine and neuro-endocrine signaling pathways, together determining contractility, cardiomyocyte hypertrophy and survival, mitochondrial function and metabolism and extracellular matrix composition [29]. Accurate determination of
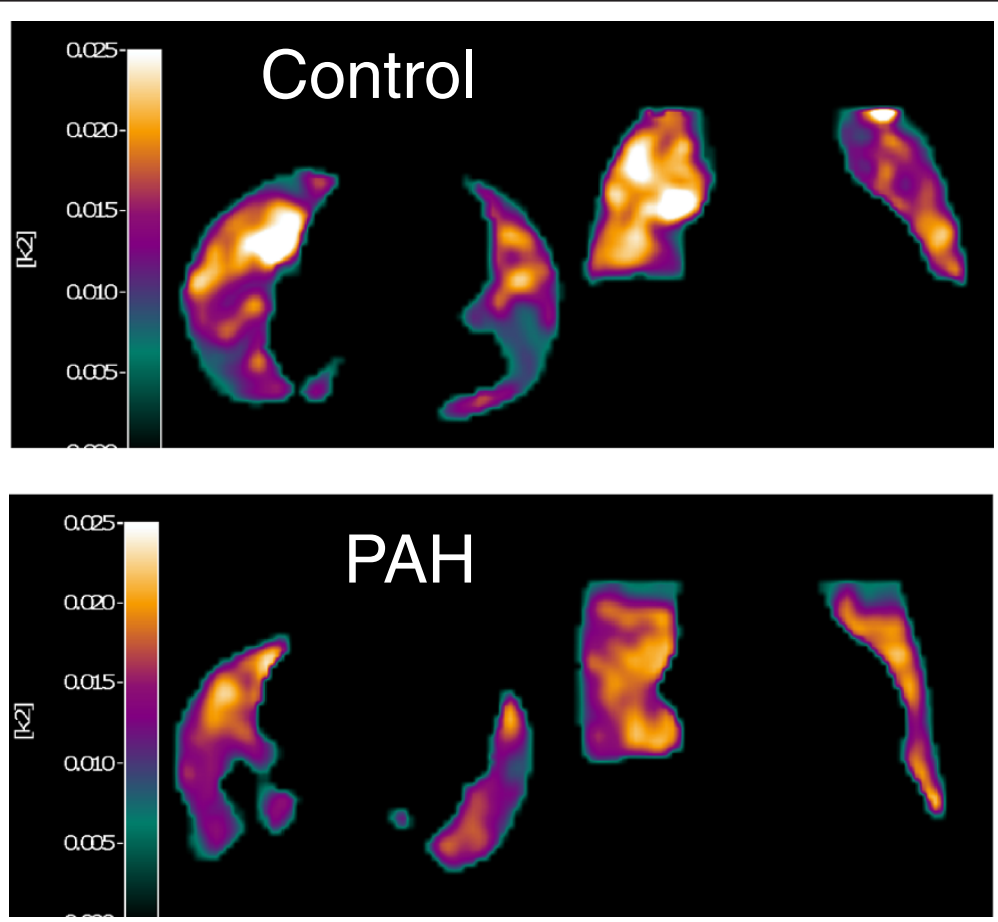

Figure $1{ }^{11} \mathrm{C}$-Acetate wash-out scans of the lungs of a control subject (upper panel) and a patient with pulmonary arterial hypertension (PAH, lower panel. There is a suggestion of a decreased acetate wash-out in the PAH patient, which is compatible with a lower oxygen uptake. This would comply with a metabolic shift in the lung characterized by a decreased glucose oxidation and an increased reliance on anaerobic metabolism. These findings need to be confirmed in a larger group of patients and controls. 
RV adaptation is highly desirable, not only when caring for individual patients but also when conducting clinical trials evaluating new treatments. A major technical limitation of cardiac PET scanning, however, is its low spatial resolution together with the presence of cardiac and respiratory movements. The small size of the normal RV prohibits use of the method in control subjects, and therefore the method has only been used to assess treatment responses in patients, or to compare patients with different disease severities. Cardiac gating of dynamic scans may improve the quality of right ventricular imaging, perhaps allowing accurate assessments of the RV in even control subjects.

\section{$R V$ blood flow and oxygen balance}

In PAH, pressure overload increases RV work and thereby augments the demand for myocardial blood flow and oxygen supply. Both can be estimated using PET. Using a combination of $\mathrm{H}_{2}^{15} \mathrm{O},{ }^{15} \mathrm{O}_{2}$ and $\mathrm{C}^{15} \mathrm{O}$ tracers, it was shown that the increased myocardial $\mathrm{O}_{2}$ demand in $\mathrm{PAH}$ patients is primarily determined by elevated pulmonary pressures and heart rate [30,31]. Whereas the normal blood supply to the RV has a considerable reserve in oxygen extraction, the myocardial oxygen extraction fraction (OEF) of resting PAH patients is significantly increased ( $70 \%$ as opposed to $45-50 \%$ in dogs) [30,32], leaving little opportunity to increase oxygen extraction during exercise. To maintain myocardial oxygen supply during exercise, RV coronary flow would have to increase. This does not seem to occur in PAH patients [30], who may have an impaired right coronary blood flow [33]. PET studies have demonstrated that $\mathrm{RV} \mathrm{O}_{2}$ supply during exercise is restricted [34]. Using adenosine stress perfusion Cardiac Magnetic Resonance, it was shown that LV and RV perfusion reserves are both decreased in $\mathrm{PAH}$, which suggests that a systemic component plays a role in the development of $\mathrm{RV}$ dysfunction [35]. An imbalance in $\mathrm{RV} \mathrm{O}_{2}$ demand and supply in PAH patients can result in ischemia, as has been illustrated by Gomez et al. using stress induced SPECT scintigraphy [36].

\section{RV metabolism}

Whether or not associated to a decrease in oxygen supply, the RV of PAH patients shows several changes in metabolism culminating in an increased glucose uptake. While the normal heart predominantly uses fatty acids as energy source, the overloaded heart switches to glucose to preserve adenosine triphosphate (ATP) supply [37]. In addition, metabolic remodeling in the pressure overloaded RV results in a greater reliance on anaerobic energy generation in the form of glycolysis [38], similarly as for the lungs. These metabolic changes resemble the changes found in lung vascular cells and have been confirmed by PET scanning in PAH patients, showing decreased fatty acid uptake (using ${ }^{11} \mathrm{C}$-palmitate as surrogate) [39] and increased ${ }^{18}$ F-FDG uptake in the RV. Decreases in pulmonary vascular resistance with vasodilator treatment have been shown to correlate with decreases in ${ }^{18}$ F-FDG uptake [40]. RV ${ }^{18}$ F-FDG uptake is numerically associated with a worse clinical profile and survival [15,41-44], but in most studies, correlations between ${ }^{18}$ F-FDG uptake and hemodynamic parameters were moderate at best. There was also a considerable discrepancy between the different studies. Recent preclinical evidence suggest that the metabolic shift towards glycolysis is not sustained during the progression of RV failure [45], which would question the use of

${ }^{18}$ F-FDG uptake as a reliable biomarker in PAH.

\section{Angiogenesis and extracellular matrix remodeling}

Preclinical studies have shown that insufficient angiogenesis in the setting of rapid RV hypertrophy results in ischemia and fibrosis $[45,46]$. Vascular endothelial growth factor (VEGF) is the major contributor to angiogenesis and adhesion molecules such as integrins are other important angiogenic modulators. By use of PET imaging with ${ }^{64} \mathrm{Cu}$ labeled $V_{E G F}$ or ${ }^{18} F$ RGD with affinity for the $\alpha_{v} \beta_{3}$ integrins, it has been possible to measure angiogenic myocardial repair in rat models of myocardial infarction [47-49]. These imaging techniques allow longitudinal monitoring of therapeutic responses and may become important in the study of pathophysiological pathways of myocardial disease processes in vivo.

\section{Neuro-hormonal signaling}

Chronic activation of the sympathetic nervous and reninangiotensin systems have been demonstrated in $\mathrm{PAH}$ patients and experimental models and are important players in progression of the disease in the heart and lungs [9]. Myocardial norepinephrine uptake is quantified by PET using the ${ }^{11} \mathrm{C}$-meta-hydroxyephedrine (HED) tracer. Pietilä showed the prognostic significance of a reduced HED uptake in heart failure patients [50], which probably reflects down-regulation of myocardial betareceptor density due to chronic hyperactivity of the sympathetic nervous system. Post-synaptic $\beta$-adrenergic receptor density can also be assessed using the ${ }^{11} \mathrm{C}-\mathrm{CGP}-12177$ tracer [51], but neither of these tracers has been used in PAH. The same is true for tracers which allow activity assessment of the renin angiotensin system [52].

\section{Hybrid imaging: PET-CT or PET-MR}

The ideal imaging modality in $\mathrm{PAH}$ would combine in vivo evaluation of pulmonary and RV function and structure, with detailed spatial information of molecular processes. PET-CT (CT: computed tomography) is readily available in the clinical and research setting and its use has significantly contributed to our insights in pathophysiological processes in cardiovascular disease. Most relevant 
to imaging in PAH, CT allows accurate determination of lung anatomy and tissue density. CT is less useful than magnetic resonance (MR) imaging when it comes to functional assessments of the RV. PET-MR is an innovative, rapidly emerging technique [53-55] which allows simultaneous anatomic and functional imaging (whereas PET and CT scans are made sequentially), quantification of perfusion and tissue characterization. The major limitation of hybrid systems with MR is that no information is obtained which allows attenuation correction of nuclear images. Although it is particularly challenging to measure density variations in the lungs, this has become an active area of research $[56,57]$.

\section{Development of new tracers}

Scientific developments lead to a continuous identification of potential treatments and new molecules relevant to the pathobiology of PAH and associated RV failure. Many of these compounds and molecules have the potential to be developed into imaging targets. The development of a new tracer is a costly and labor-intensive process, however. After identification of a promising compound, the novel tracer has to undergo several validation steps before it can be used as a radiotracer in more extensive clinical (research) studies. First, the actual radio-synthesis has to be performed using a synthetic route that is reproducible and has a sufficiently high yield. Next, preclinical studies are needed to establish stability of the compound in vivo (e.g. ingrowth of radiolabeled metabolites), to assess whether the signal is related to the biological process under study (e.g. blocking studies in case of a receptor ligand) and to develop a GMP compliant radio synthesis route. Finally, proof of concept studies need to be performed in humans. These proof of concept studies typically involve test-retest studies in small groups of patients and normal subjects to assess whether uptake is different between both subject groups. These studies are also used to develop a quantitative tracer kinetic model and to determine the variability of the model.

\section{Review}

While the pathobiological understanding of PAH and associated RV failure is increasing, there is still a great need to develop methods which can assess disease severity, and predict and monitor responses to treatment. Imaging of the most pertinent cellular and molecular processes in the lungs and heart by means of PET scanning is still undeveloped, but holds great promise. Increased proliferation rates, altered cellular metabolism and angiogenesis are those disease processes which seem most suitable to assess pulmonary vascular remodeling in PAH. RV adaptation and failure can be assessed by some of the same tracers, and also by quantification of blood flow and oxygen supply. It is unlikely that PET imaging will enter the diagnostic algorithm of $\mathrm{PAH}$, as the currently used tracers do not provide information specific to the pathobiology of PAH or any other condition associated with a high pressure in the lung (e.g. chronic thrombo-embolic pulmonary hypertension). Moreover, there is no data estimating the possible sensitivity of PET imaging in PAH. However, PET scanning may have a role in the quantification of the disease processes underlying $\mathrm{PAH}$ and $\mathrm{PAH}$ associated RV failure. As such, PET imaging may be of great interest for the purpose of treatment response monitoring. Because the development of new tracers is costly and labor intensive, further development of PET scanning in a rare disease such as PAH requires a multicenter, multinational effort geared towards rapid identification of new targets and efficient development of new tracers.

\section{Conclusions}

PET provides the opportunity to image and quantify relevant disease processes in PAH and associated RV failure, including proliferation, angiogenesis, matrix remodeling, shifts in metabolism and neurohormonal signaling. The main role of PET imaging in PAH patient management lies in the monitoring of treatment responses. With the development of additional imaging targets, PET holds a great promise for future use in $\mathrm{PAH}$ patients.

\section{Abbreviations}

CT: Computed tomography; EGF-R: Epidermal growth factor receptor: FGF-R: Fibroblast growth factor receptor; ${ }^{18} \mathrm{~F}$ : 18-fluoro; FDG: Fluoro-deoxyglucose; FLT: Fluorothymidine; MMP-9: Matrix metalloproteinase 9; MR: Magnetic resonance; PDGF-R: Platelet derived growth factor receptor; PAH: Pulmonary arterial hypertension; PET: Positron emission tomography; RGD:

Arginine-glycine-aspartic acid; RV: Right ventricle.

\section{Competing interests}

This manuscript was written on behalf of the Phaedra Consortium and supported by a grant from CVON (cardiovasculair onderzoek Nederland). HJB received a travel grant in support of an oral presentation at the 2013 ISRD/ATS conference in Shanghai, during which elements of this paper were presented. None of the authors reported any other competing interest.

\section{Authors' contributions}

All authors share responsibility for the intellectual content of this papers and contributed equally to the concept and writing of this paper. All authors read and approved the final manuscript.

\section{Author details}

${ }^{1}$ Department of Pulmonary Medicine, VU University Medical Center, PO Box 7057, Amsterdam, MB 1007, The Netherlands. ²Department of Radiology \& Nuclear Medicine, VU University Medical Center, Amsterdam, The Netherlands.

Received: 26 September 2013 Accepted: 18 November 2013 Published: 11 December 2013

\section{References}

1. D'Alonzo GE, Barst RJ, Ayres SM, Bergofsky EH, Brundage BH, Detre KM, Fishman AP, Goldring RM, Groves BM, Kernis JT, et al: Survival in patients with primary pulmonary hypertension. Results from a national prospective registry. Ann Intern Med 1991, 115:343-349.

2. Sandoval J, Bauerle O, Palomar A, Gomez A, Martinez-Guerra ML, Beltran M, Guerrero ML: Survival in primary pulmonary hypertension. Validation of a prognostic equation. Circulation 1994, 89:1733-1744. 
3. van de Veerdonk T, Kind JT, Marcus GJ, Mauritz MW, Heymans HJ, Bogaard A, Boonstra KM, Marques NW, Vonk-Noordegraaf A: Progressive right ventricular dysfunction in patients with pulmonary arterial hypertension responding to therapy. J Am Coll Cardiol 2011, 58:2511-2519.

4. Peacock AJ, Murphy NF, McMurray JJ, Caballero L, Stewart S: An epidemiological study of pulmonary arterial hypertension. Eur Respir $J$ 2007, 30:104-109.

5. Humbert M, Sitbon O, Chaouat A, Bertocchi M, Habib G, Gressin V, Yaici A Weitzenblum E, Cordier JF, Chabot F, et al: Survival in patients with idiopathic, familial, and anorexigen-associated pulmonary arterial hypertension in the modern management era. Circulation 2010, 122:156-163.

6. Nagendran J, Sutendra G, Paterson I, Champion HC, Webster L, Chiu B, Haromy A, Rebeyka IM, Ross DB, Michelakis ED: Endothelin axis is upregulated in human and rat right ventricular hypertrophy. Circ Res 2013, 112:347-354.

7. Nagendran J, Archer SL, Soliman D, Gurtu V, Moudgil R, Haromy A, Aubin C, Webster L, Rebeyka IM, Ross DB, et al: Phosphodiesterase type 5 is highly expressed in the hypertrophied human right ventricle, and acute inhibition of phosphodiesterase type 5 improves contractility. Circulation 2007, 116:238-248

8. Bogaard HJ, Natarajan R, Mizuno S, Abbate A, Chang P, Chau V, Hoke N, Kraskauskas D, Kasper M, Salloum F, et al: Adrenergic receptor blockade reverses right heart remodeling and dysfunction in pulmonary hypertensive rats. Am J Respir Crit Care Med 2010, 182:652-660.

9. de Man FS, Handoko ML, Guignabert C, Bogaard HJ, Vonk-Noordegraaf A: Neurohormonal axis in patients with pulmonary arterial hypertension: friend or foe? Am J Respir Crit Care Med 2013, 187:14-19.

10. Gomez-Arroyo J, Mizuno S, Szczepanek K, Van TB, Natarajan R, dos Remedios CG, Drake Jl, Farkas L, Kraskauskas D, Wijesinghe DS, et al: Metabolic gene remodeling and mitochondrial dysfunction in failing right ventricular hypertrophy secondary to pulmonary arterial hypertension. Circ Heart Fail 2013, 6:136-144.

11. Gabler NB, French B, Strom BL, Palevsky HI, Taichman DB, Kawut SM, Halpern SD: Validation of 6-minute walk distance as a surrogate end point in pulmonary arterial hypertension trials. Circulation 2012, 126:349-356.

12. Voelkel NF, Gomez-Arroyo JG, Abbate A, Bogaard HJ, Nicolls MR: Pathobiology of pulmonary arterial hypertension and right ventricular failure. Eur Respir J 2012, 40:1555-1565.

13. Xu W, Koeck T, Lara AR, Neumann D, DiFilippo FP, Koo M, Janocha AJ, Masri $F A$, Arroliga AC, Jennings $C$, et al: Alterations of cellular bioenergetics in pulmonary artery endothelial cells. Proc Natl Acad Sci USA 2007, 104:1342-1347.

14. Zhao L, Ashek A, Wang L, Fang W, Dabral S, Dubois O, Cupitt J, Pullamsetti

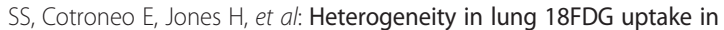
PAH: potential of dynamic 18FDG-PET with kinetic analysis as a bridging biomarker for pulmonary remodeling targeted treatments. Circulation 2013, 128:1214-1224

15. Hagan G, Southwood M, Treacy C, Ross RM, Soon E, Coulson J, Sheares K, Screaton N, Pepke-Zaba J, Morrell NW, et al: (18)FDG PET imaging can quantify increased cellular metabolism in pulmonary arterial hypertension: A proof-of-principle study. Pulm. Circ. 2011, 1:448-455.

16. Ruiter $G$, Wong $Y Y$, Raijmakers $P$, Huisman MC, Lammertsma AA, de Man FS, Westerhof N, van der Laarse WJ, Vonk-Noordegraaf A: Pulmonary 2-deoxy-2 [18F]-fluoro-D-glucose uptake is low in treated patients with idiopathic pulmonary arterial hypertension. Pulm. Circ. 2013. Epub.

17. Brown M, Marshall DR, Sobel BE, Bergmann SR: Delineation of myocardial oxygen utilization with carbon-11-labeled acetate. Circulation 1987, 76:687-696

18. Klein LJ, Visser FC, Knaapen P, Peters JH, Teule GJ, Visser CA, Lammertsma AA: Carbon-11 acetate as a tracer of myocardial oxygen consumption. Eur J Nucl Med 2001, 28:651-668.

19. Timmer SA, Lubberink M, Van Rossum AC, Lammertsma AA, Knaapen P: Reappraisal of a single-tissue compartment model for estimation of myocardial oxygen consumption by [11C]acetate PET: an alternative to conventional monoexponential curve fitting. Nucl Med Commun 2011, 32:59-62.

20. Direcks WG, Berndsen SC, Proost N, Peters GJ, Balzarini J, Spreeuwenberg MD, Lammertsma AA, Molthoff CF: [18F]FDG and [18F]FLT uptake in human breast cancer cells in relation to the effects of chemotherapy: an in vitro study. Br J Cancer 2008, 99:481-487.
21. Schermuly RT, Dony E, Ghofrani HA, Pullamsetti S, Savai R, Roth M, Sydykov A, Lai YJ, Weissmann N, Seeger W, et al: Reversal of experimental pulmonary hypertension by PDGF inhibition. J Clin Invest 2005, 115:2811-2821.

22. Al Husseini A, Bagnato G, Farkas L, Gomez-Arroyo J, Farkas D, Mizuno S, Kraskauskas D, Abbate A, Van Tassel Pharm DB, Voelkel NF, et al: Thyroid hormone is highly permissive in angioproliferative pulmonary hypertension in rats. Eur Respir J 2013, 41:104-114.

23. Overbeek MJ, Boonstra A, Voskuyl AE, Vonk MC, Vonk-Noordegraaf A, van Berkel MP, Mooi WJ, Dijkmans BA, Hondema LS, Smit EF, et al: Platelet-derived growth factor receptor-beta and epidermal growth factor receptor in pulmonary vasculature of systemic sclerosis-associated pulmonary arterial hypertension versus idiopathic pulmonary arterial hypertension and pulmonary veno-occlusive disease: a case-control study. Arthritis Res Ther 2011, 13:R61.

24. Bahce I, Smit EF, Lubberink $M$, van der Veldt $A A$, Yaqub $M$, Windhorst $A D$, Schuit RC, Thunnissen E, Heideman DA, Postmus PE, et al: Development of [(11)C]erlotinib positron emission tomography for in vivo evaluation of EGF receptor mutational status. Clin Cancer Res 2013, 19:183-193.

25. Bogaard HJ, Mizuno S, Guignabert C, Al Hussaini AA, Farkas D, Ruiter G, Kraskauskas D, Fadel E, Allegood JC, Humbert M, et al: Copper dependence of angioproliferation in pulmonary arterial hypertension in rats and humans. Am J Respir Cell Mol Biol 2012, 46:582-591.

26. Dijkgraaf I, Kruijtzer JA, Liu S, Soede AC, Oyen WJ, Corstens FH, Liskamp RM, Boerman OC: Improved targeting of the alpha(v)beta (3) integrin by multimerisation of RGD peptides. Eur J Nucl Med Mol Imaging 2007, 34:267-273

27. Dijkgraaf I, Yim CB, Franssen GM, Schuit RC, Luurtsema G, Liu S, Oyen WJ, Boerman OC: PET imaging of alphavbeta integrin expression in tumours with Ga-labelled mono-, di- and tetrameric RGD peptides. Eur J Nucl Med Mol Imaging 2011, 38:128-137.

28. Oude Munnink TH, Arjaans ME, Timmer-Bosscha H, Schroder CP, Hesselink JW, Vedelaar SR, Walenkamp AM, Reiss M, Gregory RC, Lub-de Hooge MN, et al PET with the $89 \mathrm{Zr}$-labeled transforming growth factor-beta antibody fresolimumab in tumor models. J Nud Med 2011, 52:2001-2008.

29. Bogaard HJ, Abe K, Vonk-Noordegraaf A, Voelkel NF: The right ventricle under pressure; cellular and molecular mechanisms of right heart failure in pulmonary hypertension. Chest 2009, 135:794-804.

30. Wong $Y Y$, Ruiter $G$, Lubberink $M$, Raijmakers $P G$, Knaapen $P$, Marcus JT, Boonstra A, Lammertsma AA, Westerhof N, van der Laarse WJ, et al: Right ventricular failure in idiopathic pulmonary arterial hypertension is associated with inefficient myocardial oxygen utilization. Circ Heart Fail 2011, 4:700-706.

31. Wong $Y Y$, Westerhof $N$, Ruiter $G$, Lubberink $M$, Raijmakers $P$, Knaapen $P$, Marcus JT, Boonstra A, Lammertsma AA, van der Laarse WJ, et al: Systolic pulmonary artery pressure and heart rate are main determinants of oxygen consumption in the right ventricular myocardium of patients with idiopathic pulmonary arterial hypertension. Eur J Heart Fail 2011, 13:1290-1295.

32. Kusachi S, Nishiyama O, Yasuhara K, Saito D, Haraoka S, Nagashima H: Right and left ventricular oxygen metabolism in open-chest dogs. Am J Physiol 1982, 243:H761-H766.

33. van Wolferen SA, Marcus JT, Westerhof N, Spreeuwenberg MD, Marques KM, Bronzwaer JG, Henkens IR, Gan CT, Boonstra A, Postmus PE, et al: Right coronary artery flow impairment in patients with pulmonary hypertension. Eur Heart J 2008, 29:120-127.

34. Wong $Y Y$, Raijmakers PG, Knaapen P, Lubberink M, Ruiter G, Marcus JT, Boonstra A, Lammertsma AA, Westerhof N, van der Laarse WJ, et al: Supine-exercise-induced oxygen supply to the right myocardium is attenuated in patients with severe idiopathic pulmonary arterial hypertension. Br Heart J 2011, 97:2069-2074

35. Vogel-Claussen J, Skrok J, Shehata ML, Singh S, Sibley CT, Boyce DM, Lechtzin N, Girgis RE, Mathai SC, Goldstein TA, et al: Right and left ventricular myocardial perfusion reserves correlate with right ventricular function and pulmonary hemodynamics in patients with pulmonary arterial hypertension. Radiology 2011, 258:119-127.

36. Gomez A, Bialostozky D, Zajarias A, Santos E, Palomar A, Martinez ML, Sandoval J: Right ventricular ischemia in patients with primary pulmonary hypertension. J Am Coll Cardiol 2001, 38:1137-1142.

37. Neubauer S: The failing heart-an engine out of fuel. N. Engl. J. Med. 2007 356:1140-1151. 
38. Piao L, Fang YH, Cadete VJ, Wietholt C, Urboniene D, Toth PT, Marsboom G, Zhang HJ, Haber I, Rehman J, et al: The inhibition of pyruvate dehydrogenase kinase improves impaired cardiac function and electrical remodeling in two models of right ventricular hypertrophy: resuscitating the hibernating right ventricle. J Mol. Med (Berl). 2010, 88:47-60.

39. Nagaya N, Goto Y, Satoh T, Uematsu M, Hamada S, Kuribayashi S, Okano Y, Kyotani S, Shimotsu Y, Fukuchi K, et al: Impaired regional fatty acid uptake and systolic dysfunction in hypertrophied right ventricle. J Nucl Med 1998, 39:1676-1680.

40. Oikawa M, Kagaya Y, Otani H, Sakuma M, Demachi J, Suzuki J, Takahashi T, Nawata J, Ido T, Watanabe J, et al: Increased [18F]fluorodeoxyglucose accumulation in right ventricular free wall in patients with pulmonary hypertension and the effect of epoprostenol. J Am Coll Cardiol 2005, 45:1849-1855

41. Fang $W$, Zhao L, Xiong CM, Ni XH, He ZX, He JG, Wilkins MR: Comparison of $18 F-F D G$ uptake by right ventricular myocardium in idiopathic pulmonary arterial hypertension and pulmonary arterial hypertension associated with congenital heart disease. Pulm. Circ. 2012, 2:365-372.

42. Bokhari S, Raina A, Rosenweig EB, Schulze PC, Bokhari J, Einstein AJ, Barst RJ, Johnson LL: PET imaging may provide a novel biomarker and understanding of right ventricular dysfunction in patients with idiopathic pulmonary arterial hypertension. Circ Cardiovasc Imaging 2011, 4:641-647.

43. Can MM, Kaymaz C, Tanboga IH, Tokgoz HC, Canpolat N, Turkyilmaz E, Sonmez K, Ozdemir N: Increased right ventricular glucose metabolism in patients with pulmonary arterial hypertension. Clin Nucl Med 2011, 36:743-748

44. Kluge R, Barthel H, Pankau H, Seese A, Schauer J, Wirtz H, Seyfarth HJ, Steinbach J, Sabri O, Winkler J: Different mechanisms for changes in glucose uptake of the right and left ventricular myocardium in pulmonary hypertension. J Nucl Med 2005, 46:25-31.

45. Sutendra G, Dromparis P, Paulin R, Zervopoulos S, Haromy A, Nagendran J, Michelakis ED: A metabolic remodeling in right ventricular hypertrophy is associated with decreased angiogenesis and a transition from a compensated to a decompensated state in pulmonary hypertension. J Mol Med (Berl) 2013, 91:1315-1327.

46. Bogaard HJ, Natarajan R, Henderson SC, Long CS, Kraskauskas D, Smithson L, Ockaili R, McCord JM, Voelkel NF: Chronic pulmonary artery pressure elevation is insufficient to explain right heart failure. Circulation 2009, 120:1951-1960.

47. Rodriguez-Porcel M, Cai W, Gheysens O, Willmann JK, Chen K, Wang H, Chen IY, He L, WU JC, Li ZB, et al: Imaging of VEGF receptor in a rat myocardial infarction model using PET. J Nucl Med 2008, 49:667-673.

48. Higuchi T, Bengel FM, Seidl S, Watzlowik P, Kessler H, Hegenloh R, Reder S, Nekolla SG, Wester HJ, Schwaiger M: Assessment of alphavbeta3 integrin expression after myocardial infarction by positron emission tomography. Cardiovasc Res 2008, 78:395-403.

49. Meoli DF, Sadeghi MM, Krassilnikova S, Bourke BN, Giordano FJ, Dione DP, Su H, Edwards DS, Liu S, Harris TD, et al: Noninvasive imaging of myocardial angiogenesis following experimental myocardial infarction. J Clin Invest 2004, 113:1684-1691.

50. Pietila M, Malminiemi K, Ukkonen $H$, Saraste M, Nagren K, Lehikoinen $P$, Voipio-Pulkki LM: Reduced myocardial carbon-11 hydroxyephedrine retention is associated with poor prognosis in chronic heart failure. Eur J NuCl Med 2001, 28:373-376.

51. Wichter $T$, Schafers $M$, Rhodes $C G$, Borggrefe M, Lerch $H$, Lammertsma AA, Hermansen F, Schober O, Breithardt G, Camici PG: Abnormalities of cardiac sympathetic innervation in arrhythmogenic right ventricular cardiomyopathy : quantitative assessment of presynaptic norepinephrine reuptake and postsynaptic beta-adrenergic receptor density with positron emission tomography. Circulation 2000, 101:1552-1558.

52. Fukushima K, Bravo PE, Higuchi T, Schuleri KH, Lin X, Abraham MR, Xia J, Mathews WB, Dannals RF, Lardo AC, et al: Molecular hybrid positron emission tomography/computed tomography imaging of cardiac angiotensin II type 1 receptors. J Am Coll Cardiol 2012, 60:2527-2534

53. Nensa F, Poeppel TD, Beiderwellen K, Schelhorn J, Mahabadi AA, Erbel R, Heusch P, Nassenstein K, Bockisch A, Forsting M, et al: Hybrid PET/MR imaging of the heart: feasibility and initial results. Radiology 2013, 268:366-373.

54. Schlosser T, Nensa F, Mahabadi AA, Poeppel TD: Hybrid MRI/PET of the heart: a new complementary imaging technique for simultaneous acquisition of MRI and PET data. Br Heart J 2013, 99:351-352.
55. Ibrahim T, Nekolla SG, Langwieser N, Rischpler C, Groha P, Laugwitz KL, Schwaiger M: Simultaneous positron emission tomography/magnetic resonance imaging identifies sustained regional abnormalities in cardiac metabolism and function in stress-induced transient midventricular ballooning syndrome: a variant of Takotsubo cardiomyopathy. Circulation 2012, 126:e324-e326.

56. Hofmann M, Steinke F, Scheel V, Charpiat G, Farquhar J, Aschoff P, Brady M, Scholkopf B, Pichler BJ: MRI-based attenuation correction for PET/MRI: a novel approach combining pattern recognition and atlas registration. J NuCl Med 2008, 49:1875-1883.

57. Zaidi $\mathrm{H}$ : Is MR-guided attenuation correction a viable option for dual-modality PET/MR imaging? Radiology 2007, 244:639-642.

doi:10.1186/2213-0802-1-16

Cite this article as: Harms et al:: Pulmonary vascular remodeling and right heart failure in pulmonary hypertension: future role of positron emission tomography in decoding the enigma. Translational Respiratory Medicine 2013 1:16.

\section{Submit your manuscript to a SpringerOpen ${ }^{\circ}$ journal and benefit from:}

- Convenient online submission

- Rigorous peer review

- Immediate publication on acceptance

- Open access: articles freely available online

- High visibility within the field

- Retaining the copyright to your article

Submit your next manuscript at $>$ springeropen.com 